\title{
A nyelv ritka, benignus, ectomesenchymalis chondromyxoid tumora
}

\author{
Mészáros Bence dr. ${ }^{1}$ - Vasas Béla dr. ${ }^{2}$ - Paczona Róbert dr. ${ }^{1}$ \\ ${ }^{1}$ Szegedi Tudományegyetem, Általános Orvostudományi Kar, Arc-, Állcsont- és Szájsebészeti Klinika, Szeged \\ ${ }^{2}$ Szegedi Tudományegyetem, Általános Orvostudományi Kar, Patológiai Intézet, Szeged
}

\begin{abstract}
Az ectomesenchymalis chondromyxoid tumor a szájüreg igen ritka benignus lágyrész-daganata, napjainkig mindöszszesen 93 esetet közöltek a nemzetközi szakirodalomban. Klinikailag csaknem kizárólag a nyelvhát elülső harmadában alakul ki, lassan növekvő, változatos nagyságú, fájdalmatlan, tömött, submucosus csomó formájában jelentkezik. A tumort szövetileg myxoid/chondromyxoid stromában hálózatos szerkezetbe rendeződött, kerek, poligonális vagy orsó alakú sejtek építik fel. Habár a megjelenés nagyban hasonlít a bőr és a lágyrészek myoepitheliomájára, a hisztogenezis máig nem tisztázott, azonban egy újabban megjelent, nagy esetszámot tartalmazó közlemény RREBI-MKL2 génfúziót igazolt az esetek $90 \%$-ában, ami a daganat önálló entitását bizonyíthatja. A pontos szövettani diagnózis felállitását az immunhisztokémiai vizsgálatok biztosítják. Közleményünkben egy 62 éves férfi betegünk esetét mutatjuk be, aki a nyelvcsúcsán észlelt egy $3 \mathrm{~cm}$ nagyságú, fájdalmatlan, lassan növekvő csomót. A tervezett mútéti beavatkozáson nem jelent meg, csak 4 évvel késóbb jelentkezett ismét, ekkorra a sebészi kezelésbe már beleegyezett. A daganat eltávolítását követóen 24 hónappal panaszmentes, lokális recidíva nem észlelhetó.
\end{abstract}

Orv Hetil. 2019; 160(33): 1319-1323.

Kulcsszavak: nyelv, daganat, immunhisztokémia

\section{Ectomesenchymal chondromyxoid tumor of the tongue, a rare and benign lesion}

Ectomesenchymal chondromyxoid tumor is a rare benign intraoral soft tissue neoplasm. Till date, 93 cases have been reported in literature. Clinically, it presents as a slowly growing, painless, firm, submucosal swelling mainly occurring on the anterior two thirds of the dorsum of the tongue. Histopathologically, the tumor is characterized by a well circumscribed, lobular proliferation of round, polygonal, or fusiform cells in a net-like pattern in a myxoid to chondromyxoid background. Although it shows a morphological resemblance to myoepitheliomas of soft tissue and skin, the exact histogenesis remains unclear; a recent publication of a large series has demonstrated recurrent RREBI$M K L 2$ gene fusions in $90 \%$ of the cases, suggesting the possibility of a new entity. The diagnosis is largely supported by immunhistochemical investigations. Here, we present a new case of ECT occurring in a 62-year-old male who presented with a leading complaint of slowly growing painless mass arising from the anterior part of the tongue measuring about $3 \mathrm{~cm}$. This lesion was diagnosed 4 years before recent admittance, but the patient did not undergo the scheduled surgical intervention and was lost to follow-up. As the tumor was still persisting and moderately enlarging, he came back to our clinic. Finally, the mass was completely resected; after 24 month of follow-up, he is doing well, with no signs of recurrence.

Keywords: tongue, neoplasm, immunohistochemistry

Mészáros B, Vasas B, Paczona R. [Ectomesenchymal chondromyxoid tumor of the tongue, a rare and benign lesion]. Orv Hetil. 2019; 160(33): 1319-1323.

(Beérkezett: 2019. február 19.; elfogadva: 2019. március 23.) 


\section{Rövidítések}

CK5 = citokeratin-5; CKAE1/AE3 = széles spektrumú citokeratin; EMCMT = ectomesenchymalis chondromyxoid tumor; GFAP $=$ (glial fibrillary acidic protein $)$ glialis fibrilláris savas fehérje; RNS = ribonukleinsav; SMA = ( smooth muscle actin $)$ simaizomaktin; $\mathrm{WHO}=($ World Health Organization $)$ Egész ségügyi Világszervezet

Az ectomesenchymalis chondromyxoid tumor (EMCMT) igen ritka, benignus lágyrész-tumor, amelyet új önálló klinikai entitásként először 1995-ben Smith és mtsai írtak le [1]. A tumor elsődleges lokalizációja szinte kizárólag a nyelvtest elülső harmadának dorsalis felszíne [2], de dokumentáltak a nyelv hátsó részén, a nyelvgyökön [2-6] és a szájpadláson észlelt elváltozást is [7-9]. A daganat klinikailag submucosusan elhelyezkedő, lassú növekedésü, rugalmas tapintatú, fájdalmatlan, elődomborodó, esetenként sessilis szövetszaporulat formájában manifesztálódik [2]. A pontos diagnózis a klinikai jellegzetességek, a fénymikroszkópos kép és az immunhisztokémiai vizsgálatok alapján állítható fel [10]. A nemzetközi szakirodalomban eddig mindösszesen 93 esetet publikáltak $[3,8,11-14]$; jelen közleményünkben - ismereteink szerint hazánkban elsőként - egy újabb esetről számolunk be.

\section{Esetismertetés}

Egy 62 éves férfi betegünket hónapok óta fennálló, fájdalmatlan, dominálóan bal oldali nyelvcsúcsduzzanat miatt, szövettani mintavételt követően utalták ambulanciánkra egyetemünk egyik társklinikájáról. Elmondása szerint az elváltozás megjelenése előtt a nyelvét sem fizikai, sem kémiai trauma nem érte. Fájdalmat nem említett, az elváltozás lényegesen nem zavarta sem az étkezésben, sem a beszédben. Anamnéziséből kiemelendő a gyógyszeresen kezelt, polyneuropathiával szövődött 2 -es típusú diabetes mellitus, hypertonia, ischaemiás szívbe- tegség, idült bronchitis, polyglobulia, dyslipidaemia. A dohányzást negálta, alkoholt alkalomszerúen fogyasztott. Fizikális vizsgálat során a nyelvcsúcs bal oldalán egy ép nyálkahártyával fedett, submucosusan elhelyezkedő, lebenyezett, összességében mintegy $3 \mathrm{~cm}$ átmérőjű rugalmas terimét tapintottunk. Az elváltozás középső részén, a korábbi 'punch' biopsziának megfelelően, szövődménymentesen gyógyuló, heges területet észleltünk (1. ábra). A nyelv érző- és motoros beidegzési zavarát nem tapasztaltuk, a nyakon fizikális vizsgálattal kórosan megnagyobbodott nyirokcsomót nem észleltünk. Az időközben elkészült szövettani eredmény (rupturált mucokele) birtokában az elváltozás mútéti eltávolítását javasoltuk. A hisztológiai és a klinikai kép alapján további kiegészítő képalkotó vizsgálatokat nem tartottunk szükségesnek. Betegünk sem a felajánlott mütéti időpontban, sem további ambuláns vizsgálaton nem jelent meg.

A beteg első klinikai észlelését követően mintegy 4 évvel késóbb jelentkezett újra klinikánkon. Korábban ismertetett panaszai nem változtak, az elváltozás minimális növekedését észlelte. A műtéttől való elzárkózását a szövettani mintavétel során átélt erôs fájdalomtól való félelmével, míg az elmaradt ellenőrző vizsgálatot állapotának stabil voltával és csekély tüneteivel magyarázta (1. ábra). Az ismételt mintavételt határozottan elutasította, amelyet - tekintettel a klinikailag benignus folyamatra utaló jellegzetességekre - magunk sem tartottunk elengedhetetlennek. A kezelési terv többszörös átbeszélését és egy, a beteg által kért mútéti időpont ismételt halasztását követően a daganatot végül intratrachealis narkózisban távolítottuk el (2. ábra).

A mütét során a nyálkahártya megnyitását követően jól láthatóvá vált két, egymással szorosan összetapadó kerekded képlet, melyeket a környező nyelvizomzattal együtt in toto eltávolítottunk, majd a sebet direkt módon, két rétegben zártuk. A beteget zavartalan posztoperatív szakot követően a mútét másnapján bocsátottuk otthonába.
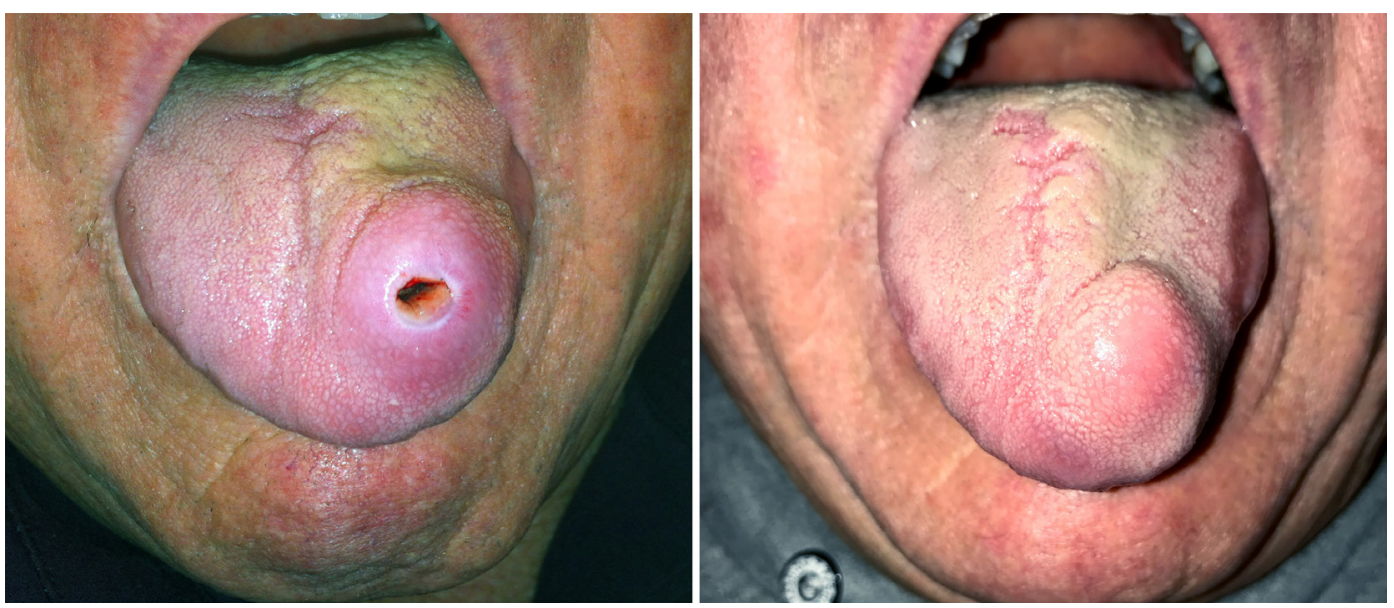

Nyelvtesti, submucosus terime, középső részén a korábbi 'punch’ biopszia gyógyuló hege (bal oldal), 4 év után továbbra is fennálló, minimális mértékben növekedett submucosus daganat (jobb oldal) 

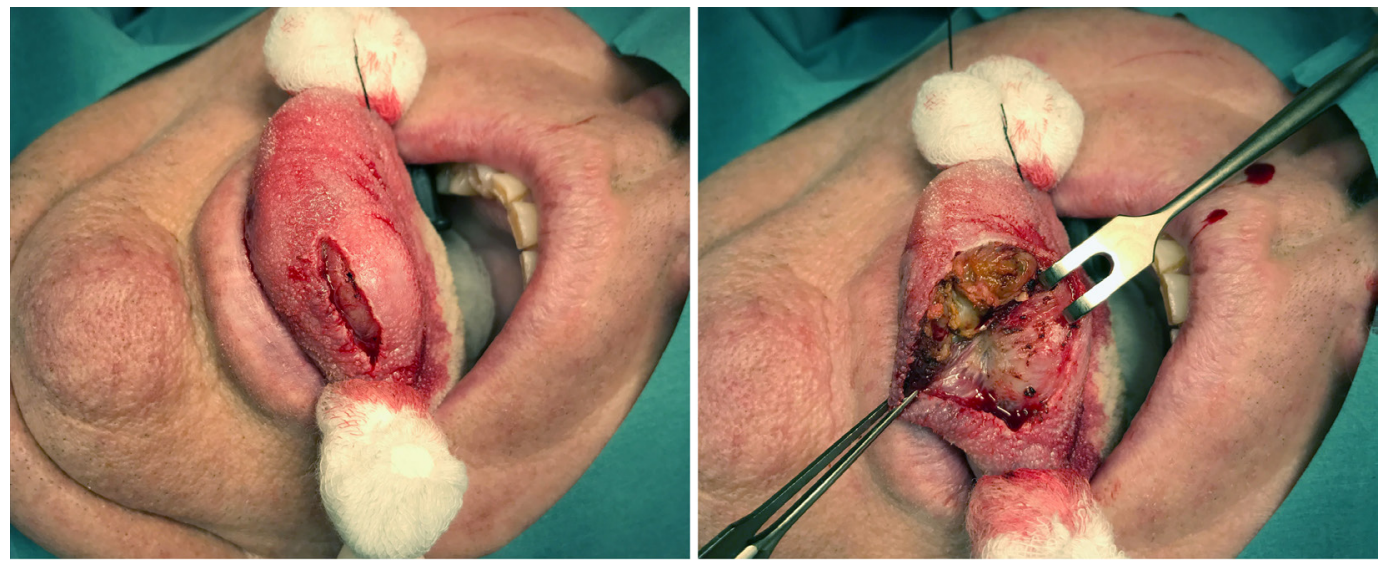

2. ábra

| A daganat mútéti eltávolításának lépései
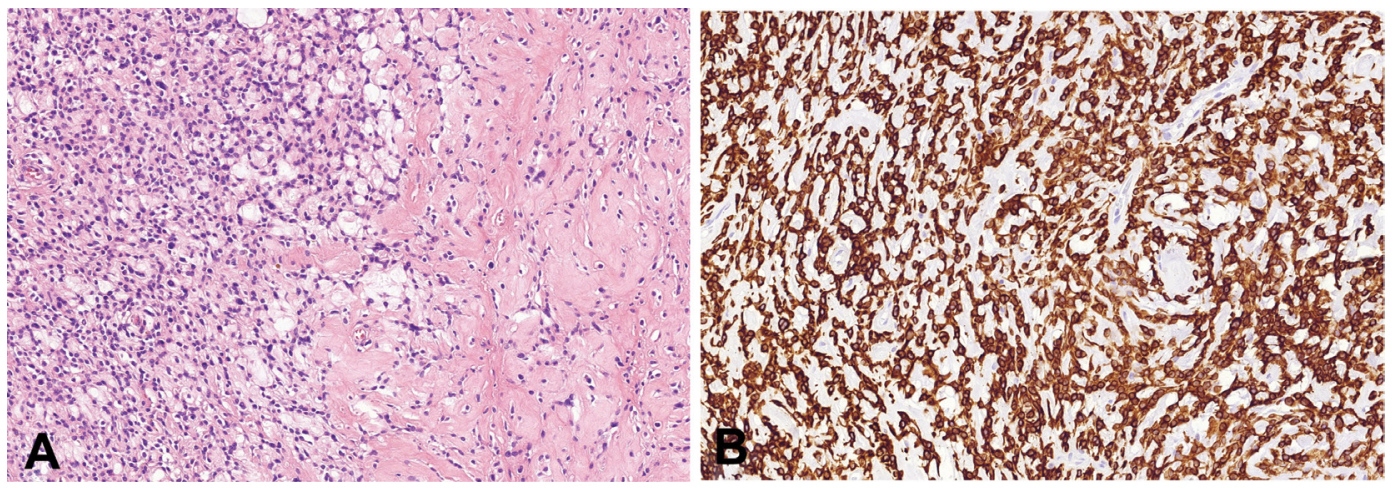

3. ábra

A daganat mikroszkópos képe. (A) A monomorf tumorsejtek hálózatos struktúrákat képeznek, sejtdús (bal oldal) és sejtszegény (jobb oldal) területek váltakoznak; a stroma myxoid és chondromyxoid jellegú, néhol a daganat gócosan porcszövetre emlékeztet (HE, 200x). (B) Immunhisztokémiai vizsgálattal a daganatra jellegzetes erős, diffúz cytoplasmaticus GFAP-expresszió mutatkozik (GFAP, $200 \times)$
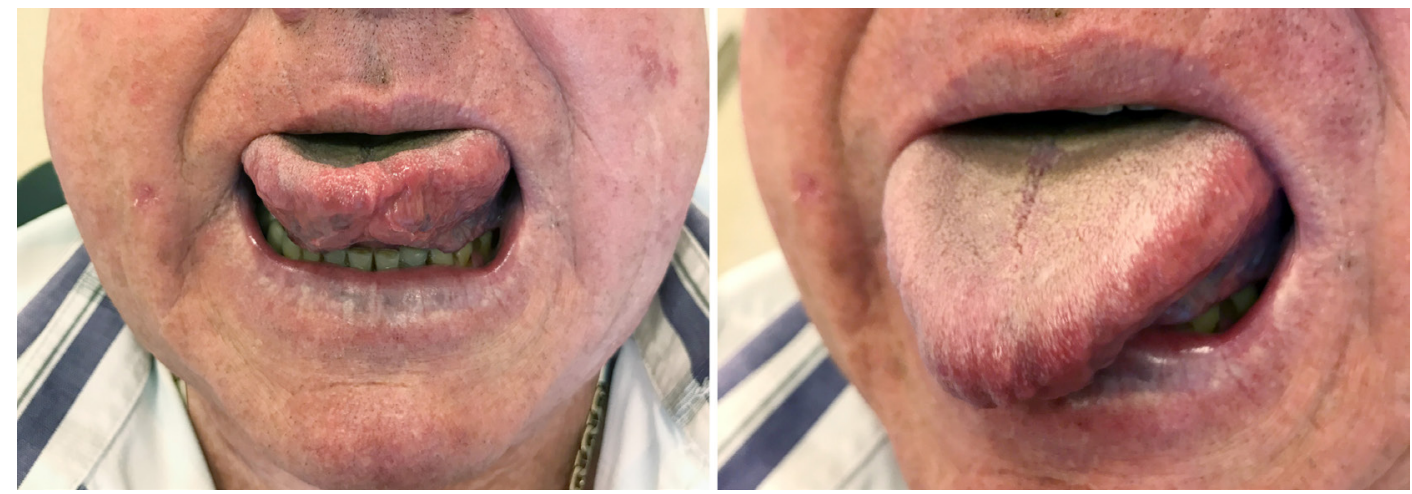

A mútéti preparátum makroszkópos patológiai vizsgálata eltérésmentes nyálkahártya alatt két, egyenként $12 \times$ $8 \times 8 \mathrm{~mm}$, illetve $12 \times 11 \times 14 \mathrm{~mm}$ átmérôjü, jól körülírt, lobulált idegen szövetet észlelt. Mikroszkóposan a nyelvizomzatban elhelyezkedő, kötőszövetes sövények által tagolt, éles határú, tok nélküli, a felszíni ép laphámmal nem kapcsolódó daganatszövet igazolódott. A daganatsejtek többnyire egyformák, kerekek, ovoidak, poligonálisak vagy megnyúltak, gyér, eosinophil cytoplasmájúak voltak, a sejtmagok sötéten ábrázolódtak, a mag- vacska nem volt feltűnő. A stroma többnyire laza, myxoid volt, ebben a tumorsejtek összefüggő hálózatos struktúrákat és keskeny kötegeket képeztek, néhol jellegzetes arteficiális hasadékképződés mutatkozott. A sejtdúsabb területek chondromyxoid mátrixot tartalmazó sejtszegény, nodularis területekkel keveredtek, amelyek nemritkán porcszövetre emlékeztettek. Ennek alapállományában, lacunaszerü struktúrákban egyesével helyezkedtek el a daganatsejtek, osztódó sejtalakok nem látszódtak. 
Immunhisztokémiai vizsgálatokkal a daganat a diffúz, erős (3+) GFAP-pozitivitás mellett csaknem diffúz, 2+ intenzitású S-100-pozitív volt (3. ábra). SMA esetében 1-3+ erősségú pozitivitás volt detektálható a tumorsejtek 50-60\%-ában, míg a p63, a kalponin, a CKAEl/ AE3, a CK5 és a CD34 negatív eredményt adott.

A látott kép, valamint az immunhisztokémiai vizsgálatok EMCMT-t igazoltak, melynek eltávolítása kompletten történt. Betegünk az utánkövetési idő alatt (24 hónap) tünetmentes, recidívára utaló klinikai jelet nem észleltünk (4. ábra).

\section{Megbeszélés}

Az EMCMT-t elsőként Smith és mtsai írták le, a tumor elnevezése a jellegzetes szövettani megjelenésre és a hisztogenezisben feltételezett differenciálatlan ectomesenchymalis őssejtre reflektál $[1,3,8]$. A daganatot a jelenlegi WHO szövettani klasszifikáció önálló entitásként kezeli [15], számos szerző azonban a lágyrészek myoepitheliomájának altípusaként vagy szájüregi variánsaként sorolja be. Habár a két entitás a morfológiát és az immunfenotípust tekintve átfedést mutat, általában elkülöníthetők egymástól $[1-4,10,16-18]$. Az EMCMT típusosan a nyelvtest elülső harmadán manifesztálódik, a nyelvgyöki és az extralingualis formák extrém ritkák. A daganat szinte bármely életkorban előfordulhat (7-78 év); az átlagéletkor 40 év körüli, a nemek közötti megoszlás egyenlő $[3,8,15]$.

Az EMCMT vezető tünete a nyelvcsúcson megjelenó fájdalmatlan szövetszaporulat, azonban leírtak már nyelvgyöki [2-4, 8, 10, 11, 19] és palatinalis [7-9] lokalizációt is. Makroszkóposan a daganat általában ép nyálkahártyával borított, sima felszínű, submucosus vagy intramuscularis, változatos nagyságú (3-50 mm), átlagosan közel 1,5 cm átmérőjü terime formájában észlelhető, egyszerű szájüregi vizsgálattal jól vizualizálható. A panaszok fennállásának ideje - a lokalizációtól függően szintén változatos, a pár hetes korai észleléstől kezdve az akár 10 éve fennálló esetekre is találhatunk példát. Az elváltozások általában a kialakulásukat követően 2,5 évvel kerülnek definitív ellátásra, ezt a késlekedést részben a daganatok fájdalmatlansága és lassú növekedése is magyarázhatja $[3,8]$.

Mivel a daganatok szinte kizárólag a nyelvtest elülső harmadára lokalizálódnak, és sebészileg könnyen eltávolíthatók, a szerzők döntő többsége képalkotó vizsgálatok segítsége nélkül végezte el a diagnosztikus és egyben terápiás kimetszést; ilyen vizsgálatok csak néhány esetben, főként nyelvgyöki elhelyezkedés esetén történtek [2-6, $10,11]$.

Az EMCMT diagnózisa a hagyományos fénymikroszkópos és immunhisztokémiai vizsgálatokon alapul [1, 2, 19, 20]. Szövetileg jól körülírt, de tokkal nem határolt lobulált daganatról van szó, amely chondromyxoid alapállományból és ovális, orsó alakú, valamint poligonális sejtekből épül fel $[8,11]$. Ezek eosinophil vagy am- phophil cytoplasmájúak, a citológiai atípia általában enyhe, esetenként elszórtan megnagyobbodott, pleiomorf magok, többmagvú sejtek és nukleáris pszeudoinklúziók előfordulhatnak. A növekedés jellegzetesen hálózatos, illetve trabecularis, ritkán microcysticus-cysticus, fészkes vagy sejtdúsabb köteges mintázatú. Mirigylumenképzés vagy plasmocytoid megjelenés nem jellemző. A mitózisok ritkák, elhalások csak kivételesen észlelhetók $[14,15]$. A legtöbb EMCMT immunreaktív GFAP-, S-100-protein-, CD57- és vimentinellenes antitestekkel, az esetek felében SMA-pozitivitás is kimutatható [8]. A széles spektrumú citokeratin, az EMA és a dezmin expressziója változatos, a p63, a miogenin és a kalponin myoepithel markerek, valamint a CD34 általában negatívak. A fénymikroszkópos kép és az immunfenotípus átfedést mutat a nyálmirigyek és a lágyrészek myoepitheliomájával $[14,15,21]$.

A daganat pontos hisztogenezise mindmáig nem ismert. Korábban néhány szerző a daganat myoepithelialis megjelenése miatt kisnyálmirigy-eredetet feltételezett, ennek azonban ellentmond az a tény, hogy a nyelvhát elülső részén - ahol a daganat a leggyakrabban előfordul - nincsenek nyálmirigyek $[8,11,22]$. A jelenleg leginkább elfogadott teória szerint a daganat a nyelv állományában az ébrényi korból visszamaradt, ganglionléc-eredetű pluripotens ectomesenchymalis őssejtekből alakul ki [1, 4, 10, 23]. A molekuláris patogenezis tisztázásában mérföldkő a Dickson és mtsai által nemrégiben publikált, 21 esetet elemző tanulmány, amelyben a szerzők RREB1-MKL2 fúziós gént és annak termékeit mutatták ki ezen daganatok 90\%-ában [14]. Az MKL2-gén a miokardinszerü protein-2 fehérjét kódolja, amely fiziológiásan a sima- és a harántcsíkolt izomszövet, valamint az idegszövet differenciációjában játszik szerepet [14]. A vizsgálat során egy daganatban EWSR 1-CREM fúzió igazolódott, míg egy másik esetében RNS-szekvenálással fúziós termék nem volt kimutatható. Az EWSR I-génátrendeződés szerepét korábban Argyris és mtsai is vizsgálták, ôk 11 EMCMT közül csupán csak 3-ban mutattak ki EWSR 1-gén-átrendeződést [24], míg Laco és $m$ tsai az általuk vizsgált 2 tumor egyikében sem igazolták ezt az eltérést [21]. Ezzel szemben a lágyrészek myoepithelialis daganataiban az esetek 45\%-ában kimutatható valamilyen EWSRl-gén-átrendeződés [25]. A jelenlegi legnagyobb esetszámú tanulmány alapján elmondható [14], hogy a molekulárisan megvizsgált EMCMT-ok csaknem mindegyike RREB1-MKL2 fúzióval jellemezhető, mely a daganat önálló entitását bizonyíthatja. A kis százalékban detektálható EWSR 1-génátrendeződések pontos patogenetikai szerepe és esetleges diagnosztikus jelentősége további kutatásra és tisztázásra szorul.

Differenciáldiagnosztikai szempontból az EMCMT-t el kell különítenünk a szájüreg egyéb benignus elváltozásaitól, úgymint a pleiomorf adenomától, a myoepitheliomától, a mucokelétől, a fibromától, a neurofibromától, a focalis oralis mucinosistól, továbbá a kis nyálmirigyekből 
kiinduló vagy laphámeredetű rosszindulatú tumoroktól $[2,8,11,16,19,22,26]$.

Az eddig publikált esetek alapján egyértelmú, hogy a kezelésben kizárólag a sebészi eltávolításnak van szerepe, a kimetszést követően a direkt zárás elegendő, lebenyes rekonstrukcióra nincs szükség [3,8].

Az EMCMT benignus daganat, prognózisa egyértelmúen kiváló, lokális kiújulás ennek ellenére - csekély számban ugyan, de - előfordul [1, 23].

Esetünk - irodalmi ritkasága mellett - az invazív beavatkozások előtti gondos érzéstelenítés elvégzésének fontosságára is felhívja a figyelmet. Egy fájdalmas beavatkozás kellemetlen élménye évekre eltántoríthatja a beteget a további orvosi ellátás igénybevételétől, ami egy benignus laesio esetén valószínúleg csak csekély, de egy malignus folyamatnál akár súlyosabb következményhez, akár tartós egészségromláshoz vezethet.

Anyagi támogatás: A közlemény megírása, illetve a kapcsolódó munka anyagi támogatásban nem részesült.

Szerzői munkamegosztás: M. B.: A cikk megírása. V. B.: A daganat szövettani vizsgálata, a közlemény erre vonatkozó részének megírása. P. R.: Az eset szakmai felügyelete, a mütét elvégzése, a közlemény átdolgozása. A cikk végleges változatát mindhárom szerző elolvasta és jóváhagyta.

Érdekeltségek: A szerzőknek nincsenek érdekeltségeik.

\section{Irodalom}

[1] Smith BC, Ellis GL, Meis-Kindblom JM, et al. Ectomesenchymal chondromyxoid tumor of the anterior tongue. Nineteen cases of a new clinicopathologic entity. Am J Surg Pathol. 1995; 19: 519-530

[2] Aldojain A, Jaradat J, Summersgill K, et al. Ectomesenchymal chondromyxoid tumor: a series of seven cases and review of the literature. Head Neck Pathol. 2015; 9: 315-322.

[3] Kato MG, Erkul E, Brewer KS, et al. Clinical features of ectomesenchymal chondromyxoid tumors: a systematic review of the literature. Oral Oncol. 2017; 67: 192-197.

[4] Cardin MJ, Fiset PO, Zeitouni AG, et al. Ectomesenchymal chondromyxoid tumour of the posterior tongue. Head Neck Pathol. 2014; 8: 329-333.

[5] Woo VL, Angiero F, Fantasia JE. Myoepithelioma of the tongue. Oral Surg Oral Med Oral Pathol Oral Radiol Endod. 2005; 99: 581-589.

[6] Seo SH, Shin DH, Kang HJ, et al. Reticulated myxoid tumor of the tongue: 2 cases supporting an expanded clinical and immunophenotypic spectrum of ectomesenchymal chondromyxoid tumor of the tongue. Am J Dermatopathol. 2010; 32: 660-664.

[7] Nigam S, Dhingra KK, Gulati A. Ectomesenchymal chondromyxoid tumor of the hard palate - a case report. J Oral Pathol Med. 2006; 35: 126-128.

[8] Truschnegg A, Acham S, Kqiku L, et al. Ectomesenchymal chondromyxoid tumor: a comprehensive updated review of the literature and case report. Int J Oral Sci. 2018; 10: 4.
[9] Gouvêa AF, Díaz KP, Léon JE, et al. Nodular lesion in the anterior hard palate. Oral Surg Oral Med Oral Pathol Oral Radiol. 2012; 114: 154-159.

[10] Yoshioka Y, Ogawa I, Tsunematsu T, et al. Ectomesenchymal chondromyxoid tumor of the tongue: insights on histogenesis. Oral Surg Oral Med Oral Pathol Oral Radiol. 2013; 115: 233240.

[11] Sato M, Harada H, Nagata C, et al. A case of ectomesenchymal chondromyxoid tumor of the tongue. J Oral Maxillofac Surg Med Pathol. 2018; 30: 134-137.

[12] AlZamel HA, AlBader A, Nawaz Bhat I. Ectomesenchymal chondromyxoid neoplasm. An unusual presentation. A case report. Int J Surg Case Rep. 2017; 41: 162-164.

[13] Almeida LY, Dominguete MH, Dominguete PR, et al. Immune cell infiltration in ectomesenchymal chondromyxoid tumor: an immunohistochemical study. Oral Oncol. 2018; 81: 112-115.

[14] Dickson BC, Antonescu CR, Argyris PP, et al. Ectomesenchymal chondromyxoid tumor: a neoplasm characterized by recurrent RREBI-MKL2 fusions. Am J Surg Pathol. 2018; 42: 12971305 .

[15] El-Naggar AK, Chan JK, Grandis JR, et al. (eds.) WHO classification of head and neck tumors. 4th edn. IARC, Lyon, 2017.

[16] Closmann JJ, Eliot CA, Foss RD. Ectomesenchymal chondromyxoid tumor: report of a case with description of histologic and immunohistochemical findings. J Oral Maxillofac Surg. 2013; 71: 545-549.

[17] Nikitakis NG, Argyris P, Sklavounou A, et al. Oral myoepithelioma of soft tissue origin: report of a new case and literature review. Oral Surg Oral Med Oral Pathol Oral Radiol Endod. 2010; 110: e48-e51.

[18] Pak MG, Kim KB, Shin N, et al. Ectomesenchymal chondromyxoid tumor in the anterior tongue: case report of a unique tumor. J Pathol Transl Med. 2012; 46: 192-196.

[19] Kannan R, Damm DD, White DK, et al. Ectomesenchymal chondromyxoid tumor of the anterior tongue: a report of three cases. Oral Surg Oral Med Oral Pathol Oral Radiol Endod. 1996; 82: 417-422.

[20] Tajima S, Koda K. A case of a CD56-expressing ectomesenchymal chondromyxoid tumor of the tongue: potential diagnostic usefulness of commonly available CD56 over CD57. Int J Clin Exp Pathol. 2015; 8: 3328-3333.

[21] Laco J, Mottl R, Höbling W, et al. Cyclin Dl expression in ectomesenchymal chondromyxoid tumor of the anterior tongue. Int J Surg Pathol. 2016; 24: 586-594.

[22] Allen CM. The ectomesenchymal chondromyxoid tumor: a review. Oral Dis. 2008; 14: 390-395.

[23] Portnof JE, Friedman JM, Reich R, et al. Oral ectomesenchymal chondromyxoid tumor: case report and literature review. Oral Surg Oral Med Oral Pathol Oral Radiol Endod. 2009; 108: e20e24.

[24] Argyris PP, Bilodeau EA, Yancoskie AE, et al. A subset of ectomesenchymal chondromyxoid tumours of the tongue show EWSR 1 rearrangements and are genetically linked to soft tissue myoepithelial neoplasms: a study of 11 cases. Histopathology 2016; 69: 607-613.

[25] Jo VY, Fletcher CD. Myoepithelial neoplasms of soft tissue: an updated review of the clinicopathologic, immunophenotypic, and genetic features. Head Neck Pathol. 2015; 9: 32-38.

[26] Leeky M, Narayan T, Shenoy S, et al. Ectomesenchymal chondromyxoid tumor: review of literature and a report of a rare case. J Oral Maxillofac Pathol. 2011; 15: 74-79.

(Mészáros Bence dr., Szeged, Kálvária sgt. 57., 6725 e-mail: dr.bence.meszaros@gmail.com) 